\title{
RELATION OF FEDERAL TAXATION TO THE FINANCING OF SMALL BUSINESS
}

\author{
WILIFORD I. KING*
}

\section{Are Small Enterprises Necessary?}

In recent years, politicians of all the leading political parties have shown great solicitude for small business. To paraphrase Lincoln, they doubtless love small businessmen because God made so many of them.

Inherently, there is nothing laudable in the fact that a business is small. Indeed, the fact that it is small may mean that its management has been too incompetent to take advantage of the opportunities for expansion which have surrounded it on all sides. Therefore, the question naturally arises as to whether small businesses may be nothing more than the vestigial remnants of a passing era. Might it not be better for society at large if all small enterprises were either eliminated or absorbed by larger and more efficient organizations? Would it not, in fact, be desirable to have one huge corporation operate all the plants in an industry? Were this done, could not unit production costs be greatly reduced by employing the most modern equipment and techniques?

The queries here made involve the basic issues concerning which socialists and adherents of free enterprise disagree. Socialists hold that the wastes of competition are so enormous that there is little prospect of any great progress toward efficiency in production until they are eliminated. The socialists can correctly point to the fact that hundreds of thousands-perhaps millions-of new enterprises are started in the United States each year, but that, a decade later, eighty or ninety percent of these undertakings no longer exist, this train of failures representing a tremendous volume of wasted efforts and shattered ambitions.

The advocates of capitalism have, of course, no alternative other than to admit these allegations. However, they contend that the advantages of capitalism are so great that they far outweigh its admittedly heavy costs. They point out that, in Russia, the only great nation experimenting with the socialistic system, production per man hour is certainly less than one-third as great as in the United States. They call attention to the destruction of individual liberty accompanying the adoption of fascism in Italy and Germany, and to the bungling ineptitude of governmental con-

- A.B., I905, LL.D., 1931, University of Nebraska; Ph.D., I913, University of Wisconsin. Professor of Economics, New York University. Chairman of the Committee for Constitutional Government. Secretary of the American Statistical Association, 1924-1934. President of the American Statistical Association, I935. Economist for the National Bureau of Economic Research, 1920-1927. 
trol of industry in the United States during the present war, and reiterate their desire to restore in this nation freedom of enterprise and freedom of competition.

Experience indicates that the assumption of the socialists that efficiency generally tends to increase with the size of an enterprise is contrary to fact. Were this an economic principle, it seems highly probable that, despite the Sherman Law and other anti-monopoly statutes, most of the production of the nation would now be carried on by a few huge corporations. But such is not the case. What instead appears to be true is that, in a given state of the arts, each industry has its own optimum size of concern. For example, in the production of steel plates and strips, only the plant costing many millions can hope to compete successfully. The enterprise turning out only a few thousand automobiles a year cannot produce cars as cheaply as can General Motors, Ford, or Chrysler, but the most efficient hub-cap manufacturer may make this specialty more cheaply than could any of the three companies mentioned, for the manufacture of this one item does not require a huge capital investment to secure the advantages of large-scale production. The chain stores have not been able to drive out the well-managed corner grocery operated by an individual proprietor. The quarter- or half-section farm has not been put out of business by the agricultural corporation owning thousands of acres. The millions of farms and stores and shops operating in the nation are not, therefore, the outmoded remains of a disappearing system, but instead represent the particular sizes of productive units best adapted to the existing state of science and organizing ability.

As previously stated, in any given year in the United States, very many thousands of new enterprises are started. Yet the total number of enterprises is not changing rapidly. This indicates that the mortality rate approximately equals the birth rate. There is a constant and strenuous struggle for survival, and only the most efficient can hope to stay in business. At any given moment, some of the small concerns are on the way out. Others have reached their optimum size and are holding their own. Still others are on their way up. Many of our great corporations have developed from small beginnings.

The desire of a successful businessman to monopolize a market is practically universal. Yet, in the United States, we have little effective monopoly in the field of manufacturing, trade, or agriculture. Why? One of the reasons is that the big concern is always being challenged by the vigorous growing small concern. If, at any time, our industries actually come under the control of powerful monopolies, it is almost certain that the voting public will insist that they be controlled or owned by government. This would mean the substitution of fascism or socialism for capitalism. It follows that the presence of large numbers of aggressive expanding small concerns is an essential feature of the competitive capitalistic system. It is, indeed, doubtful that, without the presence of such concerns, our enterprise system will long survive. 
Sources of Funds Avamlable to Smazl Enterprises

It is an obvious truth that business expansion requires additional capital. There are but two ways of obtaining such capital:

I. By inducing outsiders to invest in the business.

2. By reinvesting part of the profits of the business.

The large corporation commonly acquires funds by hiring some investment banking house to sell for it a new issue of securities. As a rule, however, investment houses do not care to bother with issues involving merely a few thousands of dollars, hence small concerns are unable to utilize their services. Instead, any outside capital secured by a small enterprise must usually come from friends or acquaintances of the proprietor or promoter.

To locate such "good angels" is, of course, no easy task. Very commonly, none exist. Furthermore, a man with a brilliant idea who has started a successful undertaking is likely to be very loath indeed to allow others to gain control of the enterprise. To avoid this danger, he must retain more than half of the common stock, and raise funds either by selling preferred stock or by borrowing. If he borrows, he is likely later to find himself in financial difficulties.

For the reasons just mentioned, the most certain, conservative, and desirable way for a successful small enterprise to secure additional resources is to save a large fraction of its own profits. Perhaps the most notable case of financing by this method is that of Henry Ford who, starting with a few thousands, built a billion dollar business without any new investment of outside capital.

From the social standpoint, this method of expansion has the outstanding merit that it is available solely for those concerns that have turned out cheaply products much desired by the public. Concerns that cannot do this never have profits large enough to make possible rapid expansion. When free competition prevails, selection for survival is therefore an automatic process based upon efficiency. This is in marked contrast to the situation which exists when some governmental bureaucrat or commission decides what enterprises are worthy of financial assistance.

Recently, Henry Wallace emphasized the importance of having the Federal Government stand ready to guarantee loans to small business concerns. There are two weaknesses inherent in this proposal. First, the lending of money to a business is often bad for the business, for it thereafter finds itself burdened with a load of fixed charges which tend to swamp it when a depression appears. Second, if the government guarantees the entire loan, the federal officials are likely to discover that it is no simple task to determine which small enterprises are good risks. If, on the other hand, the government guarantees but part of the loan, the would-be borrower will find it difficult to find a lender who will be ready to advance the remaining fraction of the loan, for, since those concerns requesting loans will tend to be those not well established, the prospective lender will consider the risk of default to be great. 
Mr. Wallace states that the war-time experience with such loans has been satisfactory. It is, however, one thing to lend to a concern having an assured market for its products in the form of a federal order for goods, and another thing to lend to a concern which merely hopes to get orders.

If instead of lending money to small enterprises, the Federal Government buys stock in the enterprise, it runs even more risk of never getting any adequate return. Furthermore, the government as a stockholder, would have a voice in directing the enterprise. Soon we might have the government in control-in which case we would have established a fascist rather than a capitalistic economy.

\section{Taxation as a Brake on Expansion}

In the past, despite lack of aid from either investment bankers or government, numerous small business enterprises have started, flourished, grown, competed successfully with large enterprises, and, occasionally, have themselves become giant undertakings. Recently, there is complaint that this broad process of evolution has bogged down. Is this because outside props have been removed? Not at all. The trouble is that the Federal Government, in exercising its taxing power, has placed major obstacles in the path of progress. ${ }^{1}$

Looking backward, we can now see that the decision of Congress in rgog to levy a tax on corporate incomes held ominous portent for business, both large and small. True, the Act of August 5, of that year seems innocuous enough. The rate was only I percent on net income, and the specific credit of $\$ 5,000$ which was allowed, helped out the small corporation. But if the Federal Government could levy a light tax, it could likewise levy a heavier one. When World War I came on, the Igr8 Revenue Act raised the corporate income tax to 12 percent, and an excess profits tax of 65 percent was levied on all net income in excess of 20 percent on invested capital. Now, in World War II, corporate incomes exceeding $\$ 50,000$ are taxed at the rate of 40 percent, while the excess profits tax is 95 percent, with a ceiling of 80 percent on combined corporate income and excess profits taxes. The very small corporation is, however, favored by the fact that \$ro,000 of excess profits is exempt from the tax; furthermore, small corporations having incomes of $\$ 50,000$ or less are taxed at rates ranging from 25 to 40 percent (exclusive, of course, of excess profits taxes).

To a large, mature corporation an exemption of 8 percent on invested capital may make the excess profits tax seem mild. By contrast, to the small concern depending for growth upon plowed-in earnings, such a tax may be paralyzing. It is now proposed that the amount of corporate annual income exempt from the excess-profits tax be increased from $\$ 10,000$ to $\$ 25,000$. Such a move would be a step in the right direction, and would help most small corporations. However, even with this additional leeway, no such meteoric rise as that of Henry Ford could possibly occur. A modest rate of growth would be the most that could take place.

\footnotetext{
I See, at the end of this article, the taxation recommendations of the Small Business Advisory Committec.
} 
Such a tax system tends, therefore, to protect from the annoying inroads of upstart rivals the large corporation which is resting on its oars. Also it prevents society from receiving the full benefits of the new ideas which have made these upstarts successful.

\section{Is Taxation of Business Sound Policy?}

A question which may be raised at this point is whether there is any legitimate excuse for levying any tax whatever upon corporations. The idea that the corporation is especially indebted to government because it is chartered by government seems specious. The corporation is merely a special form of limited-liability partnership, the privilege of organizing which ought to be an inherent part of any system of free enterprise. To pay the government for not interfering with such a contractual arrangement is much like paying a gangster for "protection." Government recognizes the ordinary partnership, as being merely an association of individuals, and taxes each partner on his share of the profits. In reality, the corporation is also merely an association of individuals, and, logically, its income ought to be dealt with on the same basis as the income of the partnership.

Logically, those who believe in the ability-to-pay principle ought to oppose the taxation of corporate incomes, for taxes on such incomes can take no cognizance of the fact that a dollar may have much greater utility to one person than to another. The rich stockholder and the poor stockholder each pay the same tax per share.

One feature of our present tax set-up is obviously unfair-that is the taxing of the total net income of the corporation and the later taxation of the dividends paid out of such net earnings to individuals. Clearly, this is double taxation, and it hampers the corporation in competing with unincorporated enterprises.

One of the reasons for taxing corporations rather than individuals is to get the corporations to act as tax collectors for the government. However, this advantage largely disappears when individual income taxes are collected from the multitudes, for it requires no more red tape to collect a larger than a smaller tax from each person.

The plain truth is that the chief reason for taxing business enterprises is to get more feathers with less squawking. The reason that this can be done is that the consumer of a concern's products rarely realizes that a tax paid by the enterprise costs him anything.

\section{TAXes on Output}

In war-time, when taxation ought to be very heavy, there is much to be said in favor of such hidden taxes as levies on corporate gross receipts or as excises collected on articles at their places of manufacture. However, any hidden tax is a direct incentive to governmental waste and extravagance; hence, in peacetime, the use of such taxes ought to be confined strictly to the raising of money for the purpose of liquidating public debt.

Objection is often made both to excise taxes and to retail sales taxes on the 
ground that such levies are not progressive-that is, they do not bear more heavily upon the rich than upon the poor. In view of the fact that our income tax on individuals is extremely progressive, this characteristic of taxes based upon sales must correctly be thought of as a merit rather than as a demerit.

Taxes on sales or on gross receipts also have the good feature of not penalizing efficiency. By contrast, all progressive income taxes or excess-profit taxes on business tend to slow down production, and encourage waste and extravagance. Only to the extent that he is actuated by patriotic motives is any corporate manager likely to work hard to keep down expenses and increase profits, if he knows that the corporation will be allowed to keep but a small fraction of the amount saved. Therefore, such progressive income and excess profit taxes can be justified, if at all, solely on the ground that, in much of war production, there is but one customerthe Federal Government-and that there is no possibility of negotiating contracts on a competitive basis. In peacetime, such taxes have no legitimate excuse for existence.

It is indeed hard to make a case for any kind of peacetime taxes on corporate incomes, and it is therefore, not surprising to find that some of the people who have been devoting attention to postwar planning advocate the complete abolition of such taxes.

\section{Indvidual-Income Taxation versus Corporate-Income Taxation}

Surprisingly enough, however, their proposals are often received without enthusiasm by the executives of large corporations. Why?

The answer is that these men know that any taxes taken off corporate income will, in all probability, be put upon individual income. They are also aware that persons having small incomes are numerous; persons having large incomes are few. Therefore, the most probable result of taking taxes off corporate profits will be to keep in existence after the war confiscatory taxes upon persons in the upper income brackets. If this is done, what will be the effect upon the financing of business?

A recent study ${ }^{2}$ by the present writer shows that most of the funds used to buy new issues of securities put out by corporations and municipal and state governments come from the savings of those persons having incomes of $\$ 5,000$ or over. The study shows that, as a matter of fact, in each of the years from 1919 to 1939 inclusive, all persons in this group, after paying their federal income taxes and after using about $\$ 3,000,000,000$ for current living expenses, tended to invest some 74 percent of all their remaining income in newly floated securities. The evidence for this conclusion rests on the fact that, by applying this simple formula, one can estimate within an average error of 20 percent the total value of new securities floated in any of the years covered by the inquiry. It appears, therefore, that taking the taxes off corporate incomes, while keeping crushing rates on the incomes of well-to-do individuals, is likely to make it very difficult for large corporations to do the financing necessary to expand their operations. This may force them to go

${ }^{3}$ King, Raising the Workingman's Scale of Living (Comm. for Constitutional Gov't, 1945). 
to the Federal Government for financing, and in this way lead to the demise of free enterprise and the advent of a fascist economy.

But how would continued confiscatory taxation of large incomes affect the small concern that is unable to float its securities through investment bankers? The obvious answer is that its difficulties are intensified even more than are those of the large corporations. The latter might be able to obtain some funds from insurance companies; the small corporations would not be likely to have this opportunity. The small corporation's chances of selling stock to individual acquaintances would be greatly reduced. Hence, the retention of anything like the existing scale of surtaxes on individual incomes is likely to make outside financing for small corporations very difficult, and compel them to depend for expansion mainly upon their own profits. Of course, abolition of corporation taxes-especially excess-profit taxes-would enhance the possibility of their having profits sufficiently large to make a reasonable amount of plowing-in feasible.

Shifting of the corporate tax burden to individual incomes would hit hard the unincorporated business, for, in such an enterprise, no clear-cut distinction exists between the individual's personal income and his business income. Any business saving comes directly out of the proprietor's pocket. Heavy surtaxes, therefore, reduce the amount that a proprietor or partner can invest in his enterprise, and so prevent the successful small business from growing rapidly into a large undertaking.

\section{Has Taxation Led to Hoarding?}

In recent years, we have heard much about heavy taxes discouraging investment and leading to hoarding of idle funds. Careful statistical investigation yields no evidence supporting the hoarding theory. Apparently this theory has been built mainly upon the erroneous hypothesis that a growing volume of bank deposits, accompanied by a reduced volume of security flotations, must mean hoarding. In reality, the two phenomena are almost entirely unrelated. Bank deposits have grown merely because the government has sold bonds to the banks and thus avoided the necessity of levying taxes. As long as the government does not retire its bonds, the deposits will remain in circulation.

That the increase of deposits is entirely unrelated to the question of unwillingness to invest is made evident if one considers what would be the result if a law were enacted and enforced requiring every depositor immediately to invest all of his deposits. The result would, of course, be the purchase of many billions of dollars worth of securities and real estate. However, after the buying was completed, the volume of deposits would be the same as it was before the investing began. Every purchase would mean a sale. The deposits would change hands, but their total volume would remain undiminished.

As noted above, the small volume of investment in new securties during the decade 1930 to $194^{\circ}$ was caused, not by any reluctance to buy or any reduction in 
the usual proportion of surplus funds invested, but solely by lack of the wherewithal with which to purchase securities.

The fact that prospective returns on invested funds are low does not necessarily discourage or prevent the investment of accumulated funds. Beggars can't be choosers. Hence, if no favorable opportunity is available, the investor is likely to take a meager return rather than to let his funds lie idle. However, low rates of return doubtless tend to discourage saving, and thus to reduce the future supply of funds available for investment.

\section{The Effect of Taxation Upon Risk Taking}

Americans are naturally a venturesome race. If profits are untaxed the man contemplating a new undertaking may figure that there is a "fifty-fifty chance" that all money put into the enterprise will be lost. However, if it is successful, the profits may be enormous. He takes the chance.

If, however, the law provides that all profit above to or 20 or 30 percent is to be taxed away, no intelligent person would consider taking such a risk. Under such circumstances, it is obviously wiser to conserve one's resources by sticking to 3 percent bonds and reasonable safety.

Persons engaged in the investment business say that our present tax laws have had a marked tendency to eliminate risk taking on the part of both individuals and corporations. If a small corporation develops a new line of products which proves very profitable, excess-profits taxes will eat up most of the revenues. However, if the venture results in a loss, the stockholders must bear the brunt-the government is interested only in case there are gains.

This tendency to eliminate risk taking may have serious effects on our economy. Most people believe that one of the chief forces making our country the outstanding industrial nation of the world has been the willingness of American entrepreneurs to try their luck on promising ventures small or large. Do we want now to substitute the safe and sure policy which, in the past, has typified European, not American industry? If so, will not our industry become static rather than dynamic?

As we have seen, it is to the advantage of the nation as a whole to have ever in action a large number of vigorous efficient small business enterprises, always forging ahead and threatening the grip on any field of industry of any group attempting to monopolize the area. To assure that this state of affairs will continue, we must encourage the plowing-in of profits and the investment of new funds in such enterprises.

\section{Who Are the Beneficiaries of Invested Capital?}

A point too frequently overlooked is that funds invested in business work just as truly for the general public as they do for the owner or owners of the enterprise. The computing scales in the grocery store, the buffing machine in a shoe-repair 
shop, the great press in an automobile factory are all helping to make goods cheaper for their ultimate users. As a matter of fact, these devices usually save for the customers many more dollars than they ever pay to the owners. It follows, therefore, that society is benefited most by whatever policy is best designed to provide enterprises big and little with the maximum amounts of tools and equipment. That policy will do this most effectively which will lead to the most saving and investment in industry. What rôle, then, ought taxation to play in this connection?

\section{Why There Should Be No Tax on Saving}

Clearly, one thing that it ought not to do is to discourage thrift and saving. This principle makes it evident that the tax on undistributed profits was one of the most positively anti-social levies ever devised. Since, as we have seen, it is the prosperous classes who do most of that individual saving which results in financing enterprise, it appears that heavy surtaxes on incomes in the upper brackets also tend to dry up the sources of investment capital, and thus prevent national progress toward higher incomes for all classes.

These taxes are justified by their advocates mainly on the ground that they prevent wasteful extravagance on the part of the rich. Is there any principle of taxation which will not slow down progress, but which will, at the same time, tend to lessen vulgar display of the power to throw money away on trivialities? The answer is yes. All that is necessary is to stop taxing savings!

According to this principle, as long as an enterprise uses its earnings to further the process of producing goods for the public, such earnings ought not to be taxed. Similarly, no individual ought to be taxed on any part of his income invested in enterprise and thus devoted to the public weal. On the other hand, there is no reason why the individual should not pay a substantial tax on that part of his income devoted to consumption. When he can afford to spend freely on luxuries, he can presumably afford to share with the government.

Two perfectly feasible devices for taxing consumption and avoiding the taxation of savings are available.

I. There may be levied excise or sales taxes with rates highest on luxury articles.

2. Dependence might be placed upon an income tax resembling our present tax in progressiveness, but exempting from taxation all savings invested during the year. Irving Fisher has shown that such exemption would not complicate materially the problem of computing the individual's tax. ${ }^{3}$

Were all saving, both corporate and individual, made exempt from taxation, the difficulty of financing any necessary expansion of a successful business enterprise would be greatly reduced. In the case of corporations of all sizes, outside financing would be made easier, for the enlarged amount of after-tax income in the hands of prosperous individuals and the additional incentive to save and invest such income would facilitate the flotation of new security issues. Furthermore, the ex-

s Fisher, Constructive Income Taxation (1942), ch. I. 
emption from taxation of income not distributed in dividends would give more opportunity for using internal savings to enlarge the business. In the case of the unincorporated business, the owner or owners would find no tax obstacles preventing the expansion of their business at as rapid a rate as its income would permit.

Since exemption of savings from taxation would necessarily mean higher taxes on consumption, the almost inevitable temporary result would be more saving and less consuming. This would increase the national supply of capital, and this increase would, in turn, cause business to flourish and tend to enlarge production and hence the national income. As the per capita income increased, the burden of taxation would gradually become easier to carry, and the proportion of the income available for consumption would expand. From the standpoint of the nation as a whole, therefore, the policy of exempting all savings from taxation appears to be the logical one to follow.

\section{Taxation Recommendattons of Small Business Advisory Commitree}

[By the Editor: After Professor King had sent in the foregoing article on the relation of federal taxation to the financing of small business, the Small Business Advisory Committee completed its preliminary study of some of the problems of small business and issued its report to the Secretary of Commerce. ${ }^{2}$ The report of this committee of businessmen is so timely ${ }^{\mathrm{b}}$ with respect to Professor King's discussion that its taxation recommendations are reproduced below in full.]

It was not possible for the Committee, with the limited time and facilities at its disposal, to make an exhaustive study of a field as complicated as that of taxation. However, in the light of its study and of the experience of its members, a statement of the general objectives of the tax system can be made, and certain inequities in the present tax structure can be indicated and remedies suggested. Moreover, in general terms the course which future tax policies should follow can be outlined and possible lines of inquiry and research suggested.

In the conversion and transitional period, the main problem is believed to center about corporate taxes; and discussion is, accordingly, limited to this field. The effect of taxes on unincorporated as well as incorporated business must be examined carefully in establishing a sound tax structure in the post-war era.

\section{General Objectives of the Tax System}

I. It should provide adequate revenue to protect the credit of the United States and safeguard the monetary system.

- Report of Small Business Advisory Committee to the Secretary of Commerce (May 15 , 1945).

At about the same time, the House and Senate's Joint Committee on Internal Revenue Taxation for Post-War issued its report containing tax recommendations in many respects similar to those of the Committee. See Commercial \& Financial Chronicle, May 24, 1945, pp. 2309, 2314-2315. 
2. It should not impose burdens on business which restrict expansion of production and employment, discourage the opening and development of new and small business, affect adversely the competitive position of small as compared to large business, or influence business decisions unduly.

3. It should distribute the tax burden equitably among all income levels insofar as that is consistent with objective No. 2. For example, the tax burden must not fall so heavily on any group as substantially to affect incentives to produce or invest or to restrict unduly the demand for consumer goods.

It is the opinion of the Committee that the present tax structure violates particularly the objectives as set forth in No. 2 above. Unless modified it will impose serious burdens on all business. On the surface, these burdens seem to apply equally to all sizes of business, but in effect they rest much more heavily on the smaller firms in the business community. Specifically, the present tax structure renders difficult the successful and quick conversion of small business to peacetime production and the launching of new firms, and tends to inhibit the growth of established small business.

\section{Conversion and Transitional Period}

Wartime tax measures which tend to prevent the reinvestment of profits have been particularly burdensome to small business concerns. Such firms, without access to the money market for equity or loan capital and with definite needs of liquid working capital for conversion and to tide them over the transitional period, will be faced with serious, and in some cases insurmountable, problems, unless the present tax provisions are liberalized. In addition to some relief from heavy taxes, steps should be taken to make immediately available certain funds which under the current tax provisions would eventually be turned over to business concerns.

\section{Excess Profits Tax}

The Committee is heartily in favor of the objective of taxing away war profits through an excess profits tax. However, the present tax is particularly burdensome to those small companies which cannot establish satisfactory prewar earning averages or which have small capitalizations in relation to business volume.

Such companies may find themselves without sufficient liquid capital for conversion and transition. Many firms will be faced with the necessity of financing the liquidation of their war business while at the same time financing conversion of plants, development of new products, and creation of new markets. Under these circumstances, even those companies which by customary standards seem to have satisfactory liquid positions may find in reality that their liquid working capital falls far short of their needs.

It is recommended, therefore, that the excess profits tax be modified to permit small businesses to build up adequate liquid working capital and to provide 
a means by which funds rightfully theirs under the present tax structure will be made immediately available.

Specifically, it is proposed that the present tax legislation be changed in the following ways:

a. Increase earnings exempt from excess profits tax from $\$$ ro,000 to $\$ 25,000$ effective January I, 1946. The stimulating effect which this would have on production suggests that loss of revenue sustained by the Treasury would not be substantial.

b. Repeal the excess profits tax effective at the beginning of the year following the end of hostilities with Japan.

c. Permit corporations to take their ro percent excess profits tax credit for I944 and subsequent years as a deduction against tax payments for those years.

d. Advance maturity of bonds representing ro percent excess profits tax credit for I94I through I943 to January I, I946.

e. Modify immediately the carry-back provisions to permit postponement of current tax payments on the previous year's taxes to the amount of estimated refunds accruing under present provisions as a result of subnormal earnings.

\section{Speed $U_{p}$ Amortization Refunds}

In order to speed up refunds resulting from recomputation of the special fiveyear amortization provision for war facilities, it is recommended that claims be allowed within ninety days from the date of filing. Allowances would be based on taxpayers' claims and returns and would be subject to recovery if later shown to be erroneous.

\section{Modification of Carry-back Provisions Applying to Deficits}

In order immediately to make available liquid working capital which would eventually belong to the company under the present law, it is proposed that firms be permitted to postpone current tax payments on the previous year's taxes to the amount of estimated refunds accruing as a result of current deficits.

\section{Tax Reduction}

Only I.a. of the above proposals would result in a reduction in taxes before the end of the Japanese War.

An analysis of the problems which will face small firms with limited capital at their disposal will, it is believed, indicate the necessity of further tax relief 
if such firms are to weather the conversion and transitional period satisfactorily.

a. For a small firm, one government contract may bear a very large relationship to its total volume of business. The impact of cutbacks and cancellations is likely to be much sharper for the small firms and involve more serious problems of readjustment.

b. Almost over night, small firms will be faced with the necessity of financing the conversion of their plants, of developing new products and of creating new markets. Small firms have had little opportunity to prepare in advance for these changes. In general, they have not been able to engage in extensive research on new products, nor have many of them been able to keep open their regular distribution channels through good will advertising during the war period. On the other hand, large companies have been able to engage in extensive research and to expand their advertising budgets, the costs for which have been considered legitimate deductible expenses.

c. The risks which small business runs in developing new products and markets are relatively very large, for these businesses must concentrate on a few products and markets and they lack the benefits of diversification which large business enjoys.

In summary, then, as compared to large business, small firms are likely to be faced with problems of more rapid conversion, their problems of developing new products and markets are greater, and their risks are very much higher.

The Committee recognizes that the Treasury's revenue needs will continue high for many years. Considering the problems faced by small business, it is believed that business taxes rest with disproportionate weight on this segment of the business population, and it is urged that steps be taken to effect a reduction.

It is recommended, therefore, that the Department of Commerce study the desirability of reducing, as of January I, I946, normal taxes and surtaxes. Such reduction might be effected by reducing the current rates, by graduating the present rates so that the maximum applies at a higher earning level, or by a combination of the above. Consideration might also be given to the possibility of a small exemption of earnings from normal taxes and surtaxes, the size of which might be related to the total number of workers employed.

\section{Post-War Period}

The Committee is unable at this time to recommend a tax structure for the post-war era. Any recommendations on this subject must depend on careful consideration of future national income and budgetary requirements. It is clear that the post-war tax structure should seek to create an environment in which the launch- 
ing of small business is not discouraged and in which small business can grow and maintain its independence.

As two of the many steps needed in this direction, the Committee recommends that the proper authorities:

r. Repeal capital stock tax and declared value excess-profits tax which are particularly burdensome to small business and complicate the tax system without providing substantial revenue to the Treasury.

2. Permit carry forward of business losses for a period of six years.

In addition, it is recommended that studies of an integrated corporate and personal tax system, which will meet the requirements of the objectives set forth, be undertaken.

The following are some of the questions which should be analyzed:

I. Effect of various types of corporate, business and personal taxes on production and employment. Particular attention should be given to the effect on all types of taxes on the birth, growth and independence of unincorporated businesses.

a. Need for greater flexibility in treatment of depreciation charges and for accelerated depreciation charges.

b. Need for provision permitting the carry forward of losses for unincorporated business for a period of six years.

c. Consideration of capital gains tax.

2. Methods of eliminating double taxation resulting from taxes on corporate earnings and on dividends received by stockholders.

a. Through a system of taxing undistributed earnings only.

b. Through a corporate tax considered only as a withholding levy.

c. Through extending to corporations the privilege of being taxed as partnerships.

The Committee believes that the Department of Commerce can play a most important role in assisting in the development of a tax structure which does not create heavy burdens for business, small and large.

I. There has been very little research on tax problems designed to test the impact of taxes on small business. To some extent this has been due to lack of readily accessible data and to lack of definite interest on the part of research agencies. The Department of Commerce should seek to:

a. Determine data necessary for such analysis.

b. Encourage research which will show empirically the impact of current or proposed federal tax legislation on small business. 
Relation of Federal Taxation to the Financing of Small Business $\quad 3^{85}$

2. Maintain contact with small businessmen and groups in order to obtain their views on tax problems.

3. Represent small business in discussions on tax matters with the Treasury, legislative committees and other agencies concerned with tax problems.

4. Stimulate and correlate research on small business tax problems in private agencies, state commissions and university research bureaus.

5. Assist the Department of the Treasury in working with State commissions in order that Federal and State taxes which bear on business may be correlated and that greater uniformity of State tax legislation may be obtained. Too frequently State taxes are imposed with regard only to revenue and without regard to the combined impact of Federal and State taxes on business or on the flow of goods among the states.

6. Publicize the tax problems of small business. 